\title{
Commentary
}

\section{Terrorism and Its Implications on National Identity}

\author{
Nasir Ahmad Ganaie ${ }^{1 *}$ \\ ${ }^{1}$ Department of Political Science, School of Social Sciences, University of Hyderabad, Gachibowlli, \\ Telangana, India \\ * Nasir Ahmad Ganaie, Department of Political Science, School of Social Sciences, University of \\ Hyderabad, Gachibowlli, CUC-500046, Telangana, India
}

Received: July 24, 2020

Accepted: August 1, 2020

Online Published: August 5, 2020

doi:10.22158/uspa.v3n3p179

URL: http://dx.doi.org/10.22158/uspa.v3n3p179

\section{Keywords}

British, colonial, defence, global, intimidation, modern weapons, national-identity, inflicting, terrorism

Terrorism as defined in oxford dictionary, "The unlawful use of violence and intimidation, especially against civilians, in the pursuit of political aims" is the world's current most deadly and destructive ailment, which is the prime threat to global reconciliation and normalcy. The terrorism had its foundation from the $18^{\text {th }}$ century onwards, and it grew out mostly from the French Revolution and later due to colonial rule and policies of the British along with their illegal occupations of almost all the major regions of the world. This British colonial strategy had resulted in its growth, and it was due to these colonial and illegal occupations that had put a considerable increase in terrorism gradually and progressively. With the passage of the time, these cruel colonial policies also resulted in the weakening of India economically (Ganaie, 2015b) and later during the pre-independence period (1947), India saw a considerable rise and growth in the form of these reform movements which were mainly due to the impact of the modern or western education on the Indian society (Ganaie, 2015a, 2015c, 2015d), despite the emergence of these reforms movements, Jammu and Kashmir in the contemporary era has been a prey of political imbalance or deception (Ganaie \& Rupavath, 2017). A country like India has been a victim of terrorism and especially since from the British rule, and it is still prevalent by dint of these British colonial policies. Lastly, India was ruled by Britishers for nearly 200 years, and they achieved political power in India only after the Battle of Plassey in 1757.

The network of terrorism in India has left no place safe, and each and every day in India, there is an incidence of terrorism activity or terror interrelated activity. Incidents of major or minor repute have frequently been happening in the parts of Jammu and Kashmir (Ganaie, 2017, 2018a) besides surge and growth in the states of the northeast. Various techniques, tactics and strategies have been used by these 
terrorist group that range from the acquisition of modern weaponry, armed training, besides funding through the adoption of local, national and international channels (Ganaie, 2018b, 2018c). There have been an enormous number of terror attacks on reputed public places in India, which have resulted in a loss of precious human lives along with the valuable public property and all these terror groups are being operated on the neighbouring soils (Anant, 2009; Ganaie, 2018a, 2018b; Jacob, 2014; Tavares, 2008).

There is no denial in the fact that there are so many laws which are meant for dealing the terror-related activities, besides a considerable presence of armed forces countering this threat without the modern weaponry and scientific technology. The Indian armed forces have been acknowledged as world's one of the most significant forces in term of size, but this is not well claimed correctly, and our armed forces who always protect and save our motherland both internally and externally are lacking the modern military technology and weaponry as compared with armed forces of countries like Britain, China, Israel, France, Germany, Russia and the United States.

The article is aimed at putting forward the viewpoint on countering terrorism and how it is possessing the biggest threat to our national identity. The biggest menace that our motherland and peaceful regions are possessing 24/7 is only through the transmission of this lethal terrorism. Our armed forces are always ready, and we must salute their duties and preparedness for fighting against these type of terrorist activities. Still, at the same time, our precious armed forces have become culprits of our politicians who are not in developing temperament. We all must acknowledge the fact that they are those ones, who do not sleep for our sleep and remain vigilant during night times even with cold temperatures and which are fed up with the darkness or they serve us even at the time of natural calamities?

The ray of hope is there, and our armed forces are being developed. Their outdated weaponry technology is being replaced with the new scientific, military technology and the first time in India's history some government at the centre is willing to develop our armed forces. Our armed forces should be developed so that they can counter it easily, besides saving their precious lives also. We should come up with a robust strategic partnership with the superpower like the United States, Russia, Israel and Britain. Besides this, there should be greater emphasis on developing our strategic partnership with the United States of America, because America itself has become a victim of this intimidation.

Our forces are least equipped with contemporary technology despite the enormous numbers, and we were always undetermined in linking a NATO treaty with the USA. We should be courageous enough to join the USA in becoming its best partner in contradicting terrorism. As we all are aware of the recurrent accidents of our air force planes, and this clearly should induce the willingness and commitment of our government in modernising our armed forces of all the three branches. We should not rely on the partnership with Russia alone, and we should become the top ally of the USA, so that modern technology, expertise and India's experience on tackling terror outfit are given some acquaintance, besides promoting full the "Make in India” project. Our air force cannot fight a two-front 
war at a time due to the shortage of fighter planes, and our government is thinking that our troops are capable of fighting a three-front war. We should admit our fault, and there should be a serious light thrown on this issue, due to the occurrence of it being a national issue, which is meant for the welfare of the whole nation. Our government and governmental agencies particularly the defence ministry should come up with a significant policy on this and serious developments should occur within all the three branches of our forces who will be then in better positions to protect our motherland. We should all keep this in mind that once our navy chief Admiral D.K Joshi had once said this "While we hope for the best, we are prepared for the worst."

The Bhartiya Janta Party (BJP) led government at the centre headed by the Narendra Modi is an ample example on this, and he is fully committed to developing our armed forces of all the three branches, viz. Land, Air and Sea. The Modi-led government should take into consideration that we have to counter China along with Pakistan. Our neighbours are not our good friends, but they always remain active in the induction of anti-India policies, and for this, it is better to be in healthier friendship with the US. The Indian side lead by Narendra Modi and his US core counterpart cum best friend Donal Trump has the best time in perplexing this bug of radicalism, and they should join hands in managing this deadly menace. This BJP government headed by Narendra Modi here in India should come out with a clear policy and separate funding for our defence sector, and a question needs to be directed to the government why we cannot place there a separate budget for our defence sector? The separate budget will be helpful in the full development of all the branches of our three forces and will make them comparable to the forces of the modern world. The operations or the tasks of countering terrorist activities is not an easy task, and it requires a considerable effort for these armed forces and as well as excellent support and cooperation from the political sector, intelligence agencies besides needing tremendous civilian cooperation.

There are several laws and anti-terror squads that are meant for coping with these menaces along with some sort of modern weaponry or technology. While dealing with the counterinsurgency operations, human rights violation should also be avoided on the first basis.

Maintaining sound and healthy relations with those countries who are affected by this menace will help a lot in tackling terrorism. India and the terror affected countries can work jointly on these issues, besides this India should launch its own new group of some member countries like USA, Israel, France, UK and Russia and anti-terror army should be created for tackling this menace jointly. Also, there must be deeper cooperation between the governments of all the nations of the world, along with the frequent exercise of all the three forces by these affected countries. Indian Governmental agencies and the rest of the terror-ridden countries should come forward, and a pact of more profound friendship and non-interference in each other internal matters should always be avoided. 


\section{References}

Anant, A. (2009). Identity and conflict: Perspectives from the Kashmir valley. Strategic Analysis, 33(5), 760-773. https://doi.org/10.1080/09700160903064554

Ganaie, N. A. (2015a). Hindu Socio-Religious Reform Movements in Jammu and Kashmir: Pre-independence phase. Asian Journal of Multidisciplinary Studies, 3(7), 94-99.

Ganaie, N. A. (2015b). Naya Kashmir, land reforms and colonialism in Jammu and Kashmir, a study of national conference and its implications on the identity of state. International Journal of Applied Research, 1(13), 565-569.

Ganaie, N. A. (2015c). Sikh Socio-Religious Reform Movements in Jammu and Kashmir from 1900-1947. International Journal of Interdisciplinary and Multidisciplinary Studies (IJIMS), 2(8), $12-16$.

Ganaie, N. A. (2015d). Socio-Religious Reform Movements of Muslims in J \& K from 1900-47. International Journal of Innovative Research and Development, 4(6), 294-298.

Ganaie, N. A. (2017). Instability and Unrest in Kashmir: A Case from Barriers of Optimism to Pellets. International Journal of Modern Social Sciences, 6(1), 51-93.

Ganaie, N. A. (2018a). Modernising Extremism: A Case of New Age Militancy in Kashmir. Advances in Politics and Economics, 1(1), 61. https://doi.org/10.22158/ape.v1n1p61

Ganaie, N. A. (2018b). Kashmir from Barriers of Discomfort to Hope: A Case of Hurriyat Conference. World Journal of Social Science Research, 5(3), 258. https://doi.org/10.22158/wjssr.v5n3p258

Ganaie, N. A. (2018c). Drama of Separatism. Urban Studies and Public Administration, 1(2), 320. https://doi.org/10.22158/uspa.v1n2p320

Ganaie, N. A., \& Rupavath, R. (2017). Impact of Kissan Credit Cards on the Socio-Economic Life of People in Jammu and Kashmir. International Journal of Modern Social Sciences, 6(1), 1-21.

Jacob, H. (2014). The Secessionist Movement in Jammu and Kashmir and India-Pakistan Relations 1. International Studies, 51(1-4), 35-55. https://doi.org/10.1177/0020881717710401

Tavares, R. (2008). Resolving the Kashmir Conflict: Pakistan, India, Kashmiris and Religious Militants. Asian Journal of Political Science, 16(3), 276-302. https://doi.org/10.1080/02185370802504316 